\title{
非晶質シリカの焼結に伴う結晶化と相転移におけるアルカリ金属酸化物の影響
}

\author{
樋口昌史・東 保男 \\ 東海大学工学部工業化学科，259-12 平塚市北金目 1117
}

\section{Effect of Alkali Metal Oxide Addition on Crystallization and Phase Transformation of Sintered Spherical Silica}

\author{
Masashi HIGUCHI and Yasuo AZUMA \\ Department of Industrial Chemistry, Faculty of Engineering, Tokai University, 1117, Kitakaname, Hiratsuka-shi, Kanagawa $259-12$
}

\begin{abstract}
A compact of spherical silica with alkali metal oxide addition was fired within a temperature range from 600 to $1200^{\circ} \mathrm{C}$ for $6 \mathrm{~h}$ in air. The crystallization and phase transformation behavior of sintered spherical silica were examined by XRD, IR, DTA, density and shrinkage measurements and SEM. The following results were obtained. (1) The silica phases formed in the sintered compacts depended on the kind and amount of added alkali metal oxide and on the firing temperature. (2) The phase transformation behavior of sintered spherical silica proceeded as follows: amorphous silica $\rightarrow$ keatite $\rightarrow$ quartz $\rightarrow$ cristobalite $\rightarrow$ tridymite. (3) Through SEM observation, it was found that molten phase formed in the sintered compacts with alkali metal oxide. The molten phase is hypothesized to be a factor determining the crystallization and phase transformation of sintered spherical silica.

[Received July 22, 1996; Accepted March 11, 1997]
\end{abstract}

Key-words : Spherical silica, Crystallization, Phase transformation, Alkali metal oxide addition, Keatite, Quartz, Cristobalite, Tridymite

\section{1. 緒言}

シリカ $\left(\mathrm{SiO}_{2}\right)$ は, 構造的に柔軟性があり熱力学的に準安定 な状態で存在できることから，多くの結晶相及び形態を有して いる1) 3)。シリカはこの多様性によりセラミックス分野で実 用的に優れた原料として多く用いられ，例えば光通信用ファイ バー, 水晶発振子, 絶縁膜, 多孔質体など様々な形態や機能を 持つ材料に応用されている。しかし材料として加工・熱処理す る際，相転移といった基本的性質に変化が起き，既知の知見内 で予測できないことが生じる。そのため，従来よりシリカの結 晶化や相転移挙動及びその物性への影響について数多く研究さ れてきた3)〜11).

シリカの相転移は, シリ力原料の形態, 処理条件及び添加物 の有無等によって影響を受ける. 常王高温下での相転移では, 転移挙動が添加物の種類・量に大きく影響を受けると考えられ て打り，その転移促進効果や関連性について多くの報告が岁 る10) 16)。しかし現在なで得られている知見は断片的なものが 多く, シリカの相転移挙動の要因を添加物によって系統的にま とめた研究例は少ない。

そこで本研究は, シリカ材料作製温度である $600 \sim 1200^{\circ} \mathrm{C}$ の 温度範囲についてシリカの相転移挙動を詳しく追跡した．シリ 力原料は高純度で均一な非晶質の単分散球状シリ力粒子を調製 して用いた。球状シリ力は形状が均一で相転移が起きにくいの でここれをシリカ原料とすれば添加物による影響を明らかにす ることができる。本報告では，合成した非晶質の球状シリカに アルカリ金属酸化物を系統的に加えて焼成処理を行い，この添 加による結晶化と相転移への影響を検討した。

\section{2. 実 験}

\section{1 単分散球状シリカの調製と焼成処理}

シリ力原料である非晶質の単分散球状シリ力粒子は，金属乃 ルコキシドの加水分解によって調製した，その製法は Stöber $ら^{17)}$ 及び下平々戸室 ${ }^{18)}$ によって報告され，東ら ${ }^{19)}$ が詳細に検 討し, 均一性の優れたサブミクロンの球状シリカを多量に得て
いる。使用した試薬は市販品で, オルトケイ酸テトラエチル (TEOS), エタノール及びアンモニア水（いずれも和光純薬工 業製, 特級) であり, 試薬は脱水, 精製等の前処理を行った。 TEOS の加水分解の条件は TEOS 濃度 : $0.1 \mathrm{~mol} / 1, \mathrm{NH}_{3}$ 濃度 : $2.0 \mathrm{~mol} / 1, \mathrm{H}_{2} \mathrm{O} / \mathrm{TEOS}=75$ (モル比) であり, 溶媒はエタ ノールを用いた。合成温度は $25^{\circ} \mathrm{C}$, 合成時間は $3 \mathrm{~h}$ とした。合 成した球状シリカは遠心分離し，エタノールで十分に洗浄を繰 り返した後 $120^{\circ} \mathrm{C}$ で一昼夜乾燥し, 更に真空乾燥を施した。

得られた球状シリカ原料に, アルカリ金属の炭酸塩を 0.5 7.0 mass\% (酸化物換算) の割合でそれぞれ添加し，めのう乳 鉢で十分に混合した。なお，アルカリ金属炭酸塩は加熱等に よって分解し, 酸化物の状態でシリカに作用すると考えられる ため, 本論文では, アルカリ金属酸化物として記述した。

各混合粉末試料は一軸方向加圧で仮成形した後, ラバープレ 又法にて $100 \mathrm{MPa}$ 下で等軸圧粉成形し, 直径 $8 \mathrm{~mm} \times$ 厚さ 8 $\mathrm{mm}$ のペレット状の成形体を得た。この成形体を石英ガラス製 試料皿上に置き，シリコニット製電気炉で焼成し室温にて放冷 した。焼成条件は, 大気圧下, 焼成温度 $600 \sim 1200^{\circ} \mathrm{C}$, 焼成時 間 6 hである。

\section{2 シリカ試料の分析方法}

焼成処理によって得られたシリ力焼成体は, 粉末状にして X線回折装置（XRD; Philips 製, X'Pert）を用いSANDMAN 検索法でシリ力結晶相の同定を行った。

シリカ焼成体のかさ密度は水銀置換によるアルキメデ久法で 測定した. シリカの熱分析は示差熱分析装置 (DTA; 理学電 機製）で行った。また，熱収縮率は自製の押棒式熱収縮率測定 装置を用いて測定した。更に，シリカ焼成体の相変化を検討す るため, 赤外線吸収スペクトル（IR; 島津製作所製, IR-435 型）を測定した。シリカ焼成体の組織観察は, 焼成体破断面を 走査型電子顕微鏡（SEM；エリオニクス製, ESA-2000型） により行い, 面組成分析は電子線マイクロアナライザー (EPMA；島津製作所製， EPMA-8705型）を用いた。 


\section{3. 結果及び考察}

3.1 アルカリ金属酸化物を添加した球状シリカの結晶化と 相転移

各種アルカリ金属酸化物を添加した球状シリ力焼成体の結晶 相をXRDにより同定した．同定結果をまとめて図 1 に示す。

高温状態でのシリカ結晶相を高温 X 線回折装置を用いて検討 した結果, 高温下で測定し同定したシリカ結晶相と，電気炬で 所定時間焼成し室温まで放冷してXRD により同定したシリカ 結晶相はほほ一致した。図 1 で決定したシリカ結晶相は試料 の冷却による影響をほとんど受けないことを確認した。

無添加の球状シリ力成形体を焼成した場合では，600〜 $1200^{\circ} \mathrm{C}, 6 \mathrm{~h}$ の焼成を施しても結晶相は認められず，X 線的に 非晶質走示した。

添加物が $\mathrm{Li}_{2} \mathrm{O}$ の場合には, $600^{\circ} \mathrm{C}$ な゙ $\mathrm{X}$ 線的に非晶質で

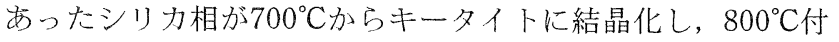
近では石英が確認された。 キータイトは従来, 高水蒸気圧下で のみ結晶化が確認されていた相9)であり, 加川ら ${ }^{15)}$ が示したよ うに, 単に焼成処理によってもキ一タイトに結晶化することを 確認した． $1000^{\circ} \mathrm{C}$ 以上の焼成では，クリストバライトとトリ ディマイトを確認した。 また， 3.0 mass \%以上の添加量が多い 焼成体には，広範用の焼成温度でリチウムケイ酸塩 $\left(\mathrm{Li}_{2} \mathrm{Si}_{2} \mathrm{O}_{5}\right.$, $\left.\mathrm{Li}_{2} \mathrm{SiO}_{3}\right)$ の生成がわずかに認められた。

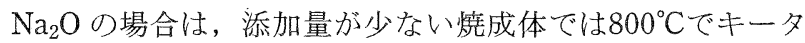
イトと石英の混合相に結晶化し，添加量が多い焼成体では $700^{\circ} \mathrm{C}$ でクリストバライトが認められた。焼成温度が高くなる 上，シリカ焼成体はクリストバライトレトリディマイトの混合 相へと変化した。また $700^{\circ} \mathrm{C}$ 付近では, ナトリウムケイ酸塩 $\left(\mathrm{Na}_{2} \mathrm{Si}_{2} \mathrm{O}_{5}\right)$ の生成が称ずかに認められた。

$\mathrm{K}_{2} \mathrm{O}$ の場合は, $700^{\circ} \mathrm{C}$ 付近からクリストバライトに結晶化し, $800^{\circ} \mathrm{C}$ かトリディマイトが形成し混合相を示した。

$\mathrm{Rb}_{2} \mathrm{O}$ の場合は, $800^{\circ} \mathrm{C}$ 付近からクリストバライト及びトリ ディマイトとの混合相が認められた.

$\mathrm{Cs}_{2} \mathrm{O}$ の場合は, $900^{\circ} \mathrm{C}$ 付近からクリストバライト及びトリ ディマイトとの混合相を示した.

$\mathrm{K}_{2} \mathrm{O}, \mathrm{Rb}_{2} \mathrm{O}$ 及び $\mathrm{Cs}_{2} \mathrm{O}$ の場合では, $\mathrm{Li}_{2} \mathrm{O} や \mathrm{Na}_{2} \mathrm{O}$ の場合に 結晶化したキータイトや石英は確認されず, ケイ酸塩の生成も
確認できなかった。また，いずれのアルカリ金属酸化物でも， 添加量が多く焼成温度が高くなるほどトリディマイトに転移す る傾向となった。

\section{2 熱収縮率及び密度の変化}

各種アルカリ金属酸化物を添加した球状シリカの焼結過程を 検討するため，熱収縮率及び密度の変化を測定した。

1.0 mass \%の各種アルカリ金属酸化物を加えた球状シリカ成 形体の昇温収縮曲線を図 2 に示す。各試料は $400^{\circ} \mathrm{C}$ 付近から収 縮を開始し始める。無添加の球状シリカは，温度上昇に伴い収 縮し， $1100^{\circ} \mathrm{C} て ゙$ 収縮率は約 $10 \%$ となる。

アルカリ金属酸化物を添加した球状シリ力成形体の収縮傾向 は，大別すると 2 通りに分かれる. $\mathrm{Li}_{2} \mathrm{O}$ 及び $\mathrm{Na}_{2} \mathrm{O}$ の場合は， $400^{\circ} \mathrm{C}$ か収縮し始め $1000^{\circ} \mathrm{C}$ 付近でやや急な収縮を示した。 $1100^{\circ} \mathrm{C}$ での収縮率は， $\mathrm{Li}_{2} \mathrm{O}$ で約 $12 \%, \mathrm{Na}_{2} \mathrm{O}$ で約 $14 \%$ となっ た。一方 $\mathrm{K}_{2} \mathrm{O}, \mathrm{Rb}_{2} \mathrm{O}$ 及び $\mathrm{Cs}_{2} \mathrm{O}$ の場合は, 高温で急激な収縮 を示した. $\mathrm{K}_{2} \mathrm{O}$ は $900^{\circ} \mathrm{C}$ 付近から, $\mathrm{Rb}_{2} \mathrm{O}$ は $950^{\circ} \mathrm{C}$ 付近から, $\mathrm{Cs}_{2} \mathrm{O}$ は $1000^{\circ} \mathrm{C}$ 付近から急激な収縮を始める. $1100^{\circ} \mathrm{C}$ での収縮 率は $\mathrm{K}_{2} \mathrm{O}$ で約 $28 \%, \mathrm{Rb}_{2} \mathrm{O}$ で約 $32 \%, \mathrm{Cs}_{2} \mathrm{O}$ については更に高 い収縮率を示した。

次に各種アルカリ金属酸化物 1.0 mass\%を添加した球状シリ

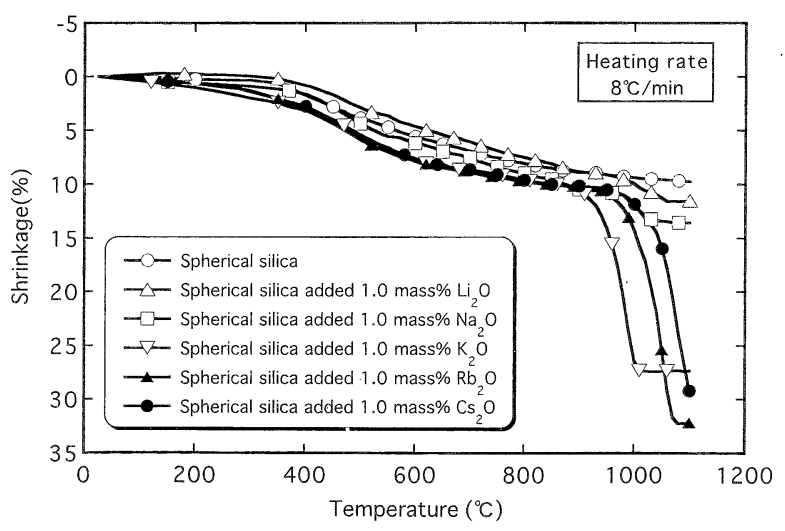

Fig. 2. Shrinkage curves of spherical silica compacts with 1.0 mass $\%$ alkali metal oxide addition.

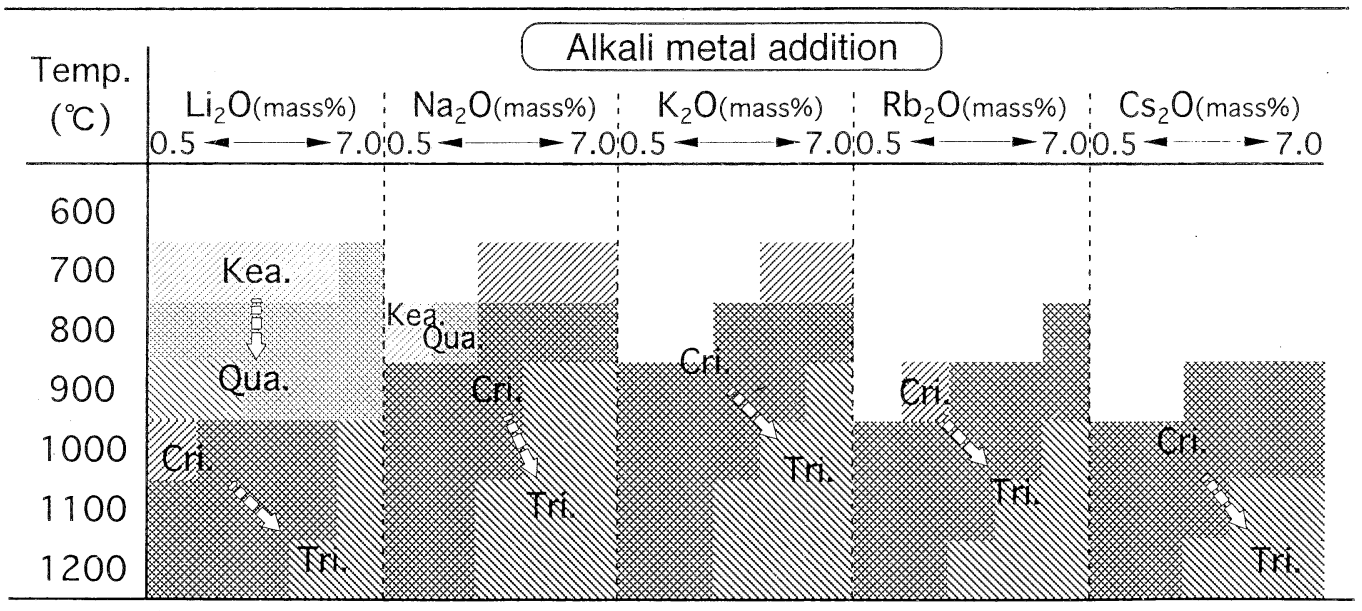

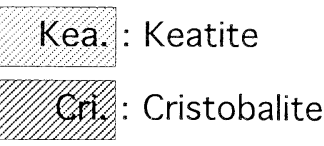

Qua.: Quartz

Tridymite

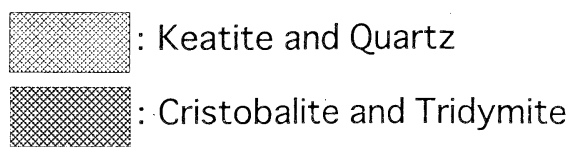

Fig. 1. Crystallization and phase transformation behavior of sintered spherical silica compacts. 


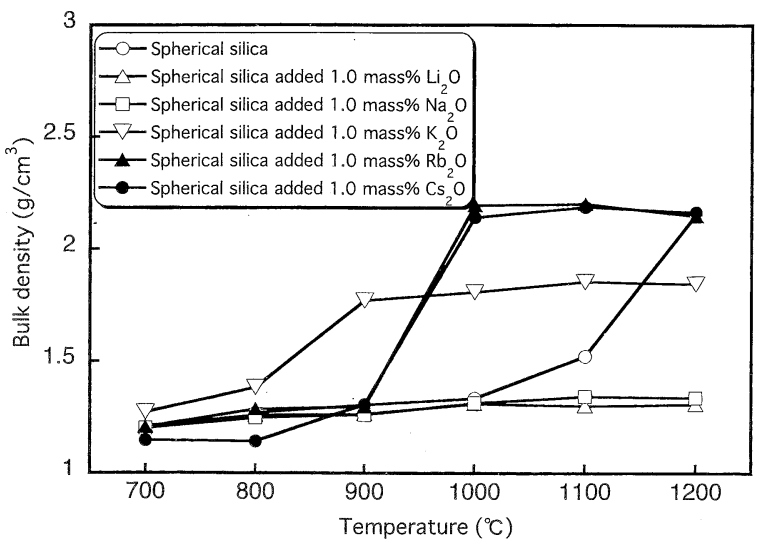

Fig. 3. Bulk densities of spherical silica compacts with 1.0 mass \% alkali metal oxide addition fired at various temperatures for $6 h$.

力焼成体の温度によるかさ密度の変化を図 3 に示す．球状シリ 力のみでは，焼結による緻密化により， $1100^{\circ} \mathrm{C}$ かかさ密度 の增加が認奶られた。添加物が $\mathrm{Li}_{2} \mathrm{O}, \mathrm{Na}_{2} \mathrm{O}$ の場合では, 高温 においても密度はほとんど変化しなかった。この結果から, $\mathrm{Li}_{2} \mathrm{O}, \mathrm{Na}_{2} \mathrm{O}$ を添加したシリカ焼成体は多孔質構造を有すると 推定される. $\mathrm{K}_{2} \mathrm{O}, \mathrm{Rb}_{2} \mathrm{O}$ 又は $\mathrm{Cs}_{2} \mathrm{O}$ の場合では, 約 $900^{\circ} \mathrm{C}$ 付近 から急激なかさ密度増加を示し, これら添加物の影響により構 造がかなり繳密化すると考えられる。

これらの結果から各シリカ焼成体の熱収縮率々かさ密度の值 との間には明らかな相関関係が認められた。すなわち, 焼成体 のかさ密度は收縮率が大きい場合に高くなった。

\section{3 アルカリ金属酸化物を添加した球状シリカのDTA 分} 析

アルカリ金属酸化物 1.0 mass $\% \mathrm{Li}_{2} \mathrm{O}, 1.0$ mass $\% \mathrm{~K}_{2} \mathrm{O}$ 又は 1.0 mass\% $\mathrm{Cs}_{2} \mathrm{O}$ を添加した球状シリカのDTA 曲線を図 4 に 示す. 1.0 mass\% $\mathrm{Na}_{2} \mathrm{O}$ を添加した場合の DTA 曲線は $\mathrm{Li}_{2} \mathrm{O}$ の場合に類似し， 1.0 mass\% $\mathrm{Rb}_{2} \mathrm{O}$ を添加した場合は $\mathrm{Cs}_{2} \mathrm{O}$ の

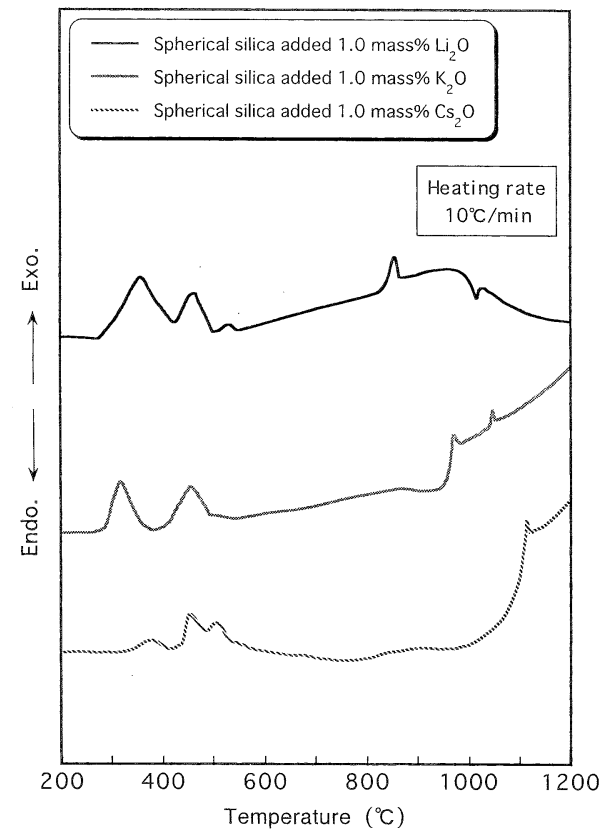

Fig. 4. DTA curves of spherical silica compacts with 1.0 mass $\%$ $\mathrm{Li}_{2} \mathrm{O}, \mathrm{K}_{2} \mathrm{O}$ or $\mathrm{Cs}_{2} \mathrm{O}$ addition.
場合と類似した曲線を示した。

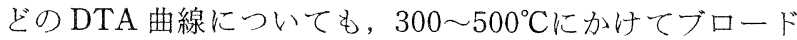
な比較的大きい発熱ピークが確認された．この発熱ピークは， 球状シリ力の調製の際に残存する有機物が燃焼することによっ て生じるものと考えられる. 同様のピーク挙動はゾルーゲル法 を用いて作製されたシリカゲルの DTA 曲線の報告20),21)でも 認められている。 また，各炭酸塩の熱分解に伴う吸熱ピークは 炭酸塩の添加量が少ないため確認できなかった。

高温領域では，添加物によって異なる DTA 曲線の挙動を示 した. $\mathrm{Li}_{2} \mathrm{O}$ の場合, $860^{\circ} \mathrm{C}$ 付近に発熱ピークがあり, $1000^{\circ} \mathrm{C}$ 付近に吸熱ピークが認められた。固体反応に打いて，低温安定 相から高温安定相への転移現象の場合は吸熱を示し，ガラ久な ぞ非晶質な物質の結晶化の場合は発熱を示す22). $860^{\circ} \mathrm{C}$ 付近 の発熱ピークは非晶質からキータイトあるいは石英の結晶化に 相当すると推定され，図 1 の結晶化温度とほぼ一致した。 た， $1000^{\circ} \mathrm{C}$ 付近の熱変化は石英からクリストバライトの転移 熱に相当すると考えられ，図 1 の転移温度とほぼ一致した。 次に $\mathrm{K}_{2} \mathrm{O}$ の場合, $960^{\circ} \mathrm{C}, 1040^{\circ} \mathrm{C}$ 付近に小さな発熱ピークがあ り， $\mathrm{Cs}_{2} \mathrm{O}$ の場合では $1100^{\circ} \mathrm{C}$ 付近に発熱ピークが認められた。 これらの発熱ピークは図 1 の結果から, 非晶質からクリス卜 バライトあるいはトリディマイトへの結晶化熱に相当すると推 定される.しかし非晶質を示す球状シリカの結晶化は単純に起 こるのではなく, 球状シリカの焼結過程でガラ大に類似した相 が形成されることや23)，結晶化するクリストバライトやトリ ディマイトの形成量や転移過程について不明な点があり，今後 更に検討する必要がある。

\section{4 シリカ結晶相のIR スペクトル分析}

シリカの特徵的な吸収ピークは， $470 \sim 620 \mathrm{~cm}^{-1}, 680 \sim 800$ $\mathrm{cm}^{-1}$ 及び1000 $1200 \mathrm{~cm}^{-1}$ 付近にある 20,21$\left.), 24\right)$.

図 5 に 1.0 mass\% $\mathrm{Li}_{2} \mathrm{O}$ を添加して焼成した球状シリ力の各 温度におけるIRスペクトルを示す。温度上昇に伴い，吸収 ピークの成長と消失による变化が認められた。いずれのシリカ 焼成体も添加物の影響による各結晶相の IR スペクトルの変化 がほとんどなく，各結晶相に起因する吸収ピークが得られた。 そこでシリカ焼成体に抢けるIR スペクトルの吸収ピークを結 晶相別に分類した。その結果を図 6 に示す。

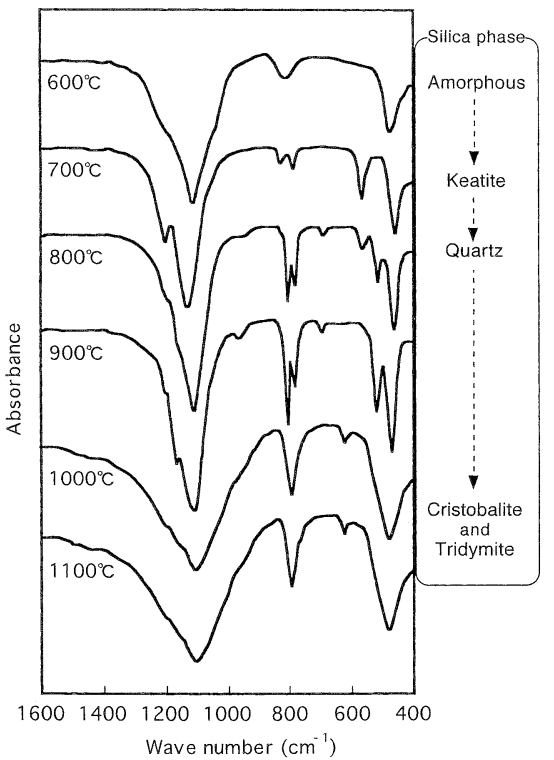

Fig. 5. IR spectra of spherical silica compacts with 1.0 mass\% $\mathrm{Li}_{2} \mathrm{O}$ addition fired at various temperatures for $6 \mathrm{~h}$. 


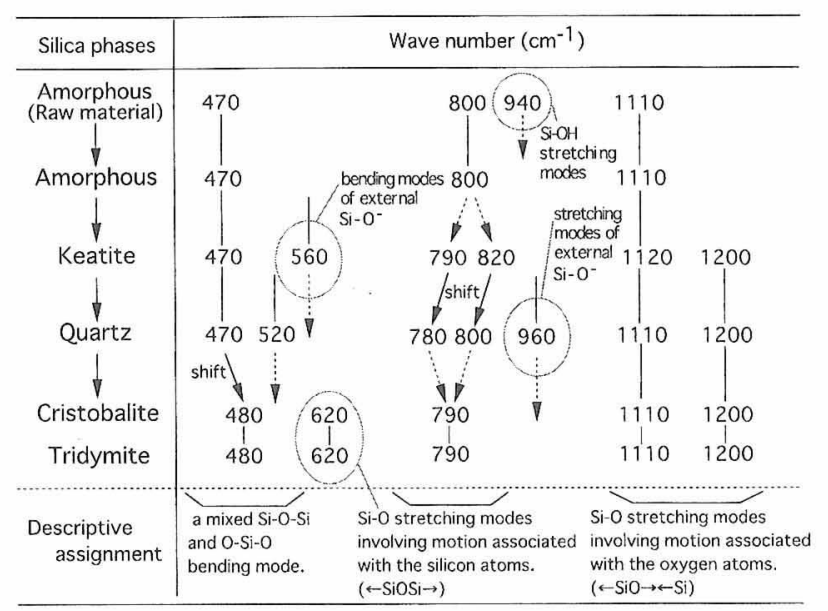

Fig. 6. Absorption bands in IR spectra of silica phases formed from sintered spherical silica compacts.

非晶質を示す球状シリカが加熱されると, $\mathrm{Si}-\mathrm{OH}$ 伸縮振動 による $940 \mathrm{~cm}^{-1}$ の吸収ピークが消失し, Si-OH の脱水が起こ る。非晶質からキ一タイトに結晶化すると, $560 \mathrm{~cm}^{-1}$ の SiO-变角振動が認められた. $1120 \mathrm{~cm}^{-1}$ の吸収に加えて, $1200 \mathrm{~cm}^{-1}$ のO 原子の動きに関連する非対称性 Si-O 伸縮振動 が確認された。 また，Si 原子の動きに関連する対称性 Si-O 伸 縮振動を示す $800 \mathrm{~cm}^{-1}$ の吸収ピークが，790と $820 \mathrm{~cm}^{-1}$ の二 つの吸収ピークとなった.

キータイトが石英に転移すると，520と960 $\mathrm{cm}^{-1}$ の吸収 ピークが生じる. $520 \mathrm{~cm}^{-1}$ の吸収は $470 \mathrm{~cm}^{-1}$ と同じ Si-OSi 及び O-Si-O の変角振動を示し, $960 \mathrm{~cm}^{-1}$ は Si-O- 伸縮振 動で影る。これらの吸収ピークの变化から，非晶質中に存在し た $\mathrm{Si}-\mathrm{OH}$ が加熱により脱水して Si-O-などを形成し，更に $\mathrm{Si}-\mathrm{O}-\mathrm{Si}$ の重縮合が起きるものと推察される.

次に，石英がクリストバライトとトリディマイトに転移する と, 520,560 及び $960 \mathrm{~cm}^{-1}$ の吸収ピークが消失し，新たに対 称性 Si-O 伸縮振動を示す $620 \mathrm{~cm}^{-1}$ の吸収が認められた。 た， $470 \mathrm{~cm}^{-1}$ の Si-O-Si 及び O-Si-O の変角振動を示す吸収 ピークは $480 \mathrm{~cm}^{-1}$ にシフトした.これは転移による結晶構造 の変化により, Si-O の結合距離, 結合伸縮力及び結合角度が 変化したことを示す. キータイト及び石英中の 790 と $820 \mathrm{~cm}^{-1}$ の二つの吸収ピークは, 対称性 $\mathrm{Si}-\mathrm{O}$ 伸縮振動を示す $790 \mathrm{~cm}^{-1}$ の一つの吸収ピークとなった。

シリカ相が非晶質からキータイトと石英に結晶化するとさ， 及び石英からクリストバライトとトリディマイトに転移すると きに，IR スペクトルの吸収ピークは大きな変化を伴うことか ら，IR スペクトルの測定はシリカ相の同定に有効であること を認めた、本実験のIR スペクトルの測定結果は先の XRDに より追跡した相転移挙動と一致した.

\section{5 シリカ相の組織観察}

シリ力焼成体の各相を SEMにより観察した。図 7 は, 1.0 mass\%及び 5.0 mass\% $\mathrm{Li}_{2} \mathrm{O}$ を添加したシリ力焼成体の組織を 示したSEM 写真である. 図 7 (a) は球状シリ力原料で約 0.6 $\mu \mathrm{m}$ の均一な球状粒子が確認できる. 球状シリ力に 1.0 mass \% $\mathrm{Li}_{2} \mathrm{O}$ を添加して $800^{\circ} \mathrm{C}, 6 \mathrm{~h}$ で焼成した焼成体の破断面の組織を 図 7 (b)に示す.この焼成体中では球状シリ力粒子の痕跡が認 められる融合状態と板状の結晶が多く形成されていることが確 認できる. $1000^{\circ} \mathrm{C}$ (図7 (c))の焼成では, 球状シリ力がさら に融合した状態を示す。 $1200^{\circ} \mathrm{C}$ (図 7 (d)) では球状シリカ粒

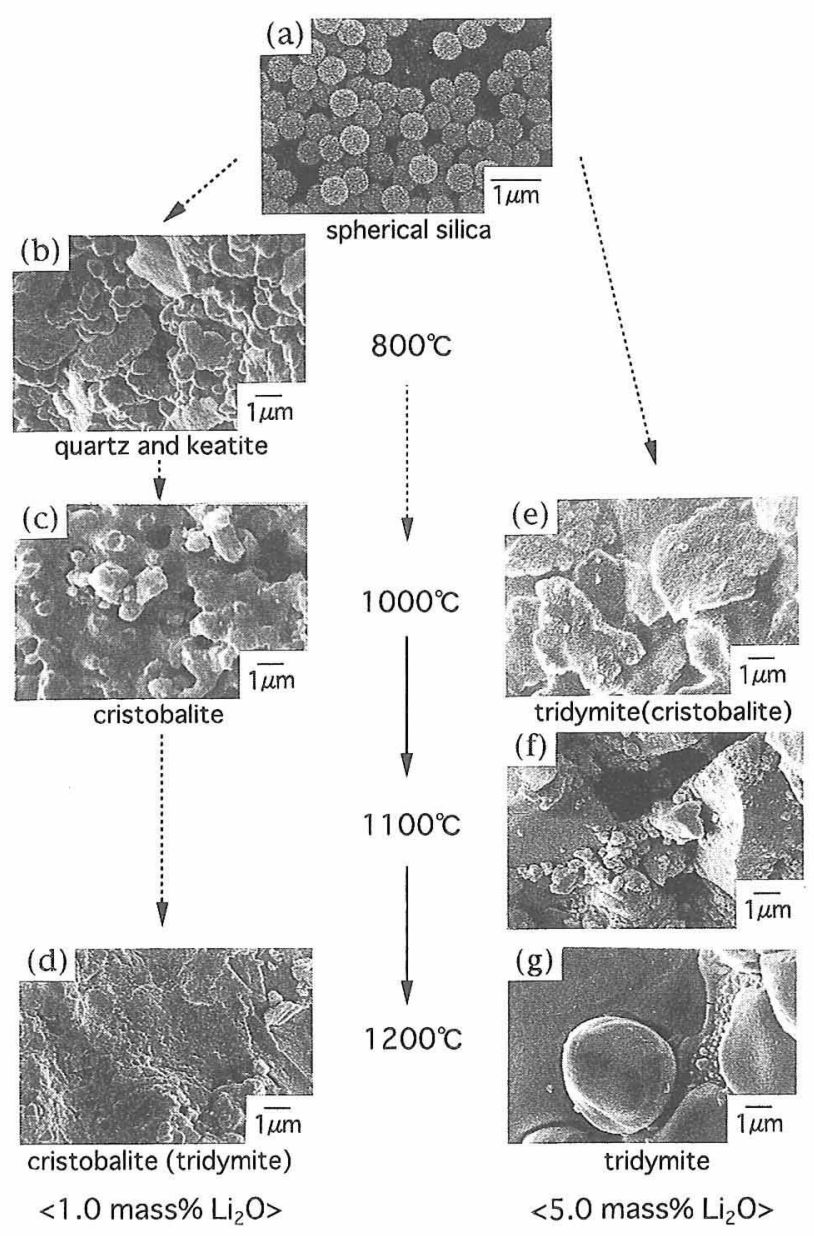

Fig. 7. SEM photographs of sintered spherical silica with $\mathrm{Li}_{2} \mathrm{O}$ addition.

子の痕跡が認めら机ず，焼成体内一面に溶融した層が広がり， 層には小さな結晶粒が混在する。一方 5.0 mass $\% \mathrm{Li}_{2} \mathrm{O}$ を添加 した場合は， $1000^{\circ} \mathrm{C}$ (図 7 (e)) 焼成で溶融した状態を示し, $1100^{\circ} \mathrm{C}$ (図 7 (f)) では比較的大きな結晶粒の存在が見られた. この結晶粒は更に結晶成長し, $1200^{\circ} \mathrm{C}$ (図 $7(\mathrm{~g})$ ) ではトリ ディマイトと思われる大きな結晶粒を形成した。

次に $\mathrm{K}_{2} \mathrm{O}$ を添加した場合の焼成体の SEM 写真を図 8 に示 す. 1.0 mass $\% \mathrm{~K}_{2} \mathrm{O}$ を添加した場合では, $800^{\circ} \mathrm{C}$ (図 8 (a)) の焼成体で球状シリ力の融合状態が存在する. こ㧈らの融合状 態は温度が上昇するにつれて全体的に広がる（図 $8(\mathrm{~b})$ )。 $1200^{\circ} \mathrm{C}$ (図 8 (c) 1) では, 焼成体一面に溶融した層が形成さ れ，この層が多数成長した結晶粒を覆った組織が見られる. 結 晶粒は HF 水溶液で腐食した図 8 (c)2 2ではっきりと確認でき る.一力 5.0 mass $\% \mathrm{~K}_{2} \mathrm{O}$ を添加した場合は, $800^{\circ} \mathrm{C}$ (図 8 (d)) でほほ完全に溶融した層を示した，この溶融層中には結晶粒が 存在し，これはXRDの結果からクリストバライトと同定され る. 更に温度の高い焼成体になると, 溶融層中の結晶粒は成長 し, 図 $8(\mathrm{~g})$ のような大きいトリディマイトの結晶が形成され た.

$\mathrm{Cs}_{2} \mathrm{O}$ を添加した場合も $\mathrm{K}_{2} \mathrm{O}$ の場合と同様に, 添加量が多い 焼成体ほど溶融した層を形成し，その中で結晶が成長している ことが確認された。 5.0 mass\% $\mathrm{Cs}_{2} \mathrm{O}$ を添加した焼成体の SEM 写真が図 9 で山る. $1000^{\circ} \mathrm{C}$ 以上では溶融層が一面に広が り，その下には図9(a)1のような多数の結晶粒が存在してい る.この溶融層中には微粒子が点在しているのが確涩された。 


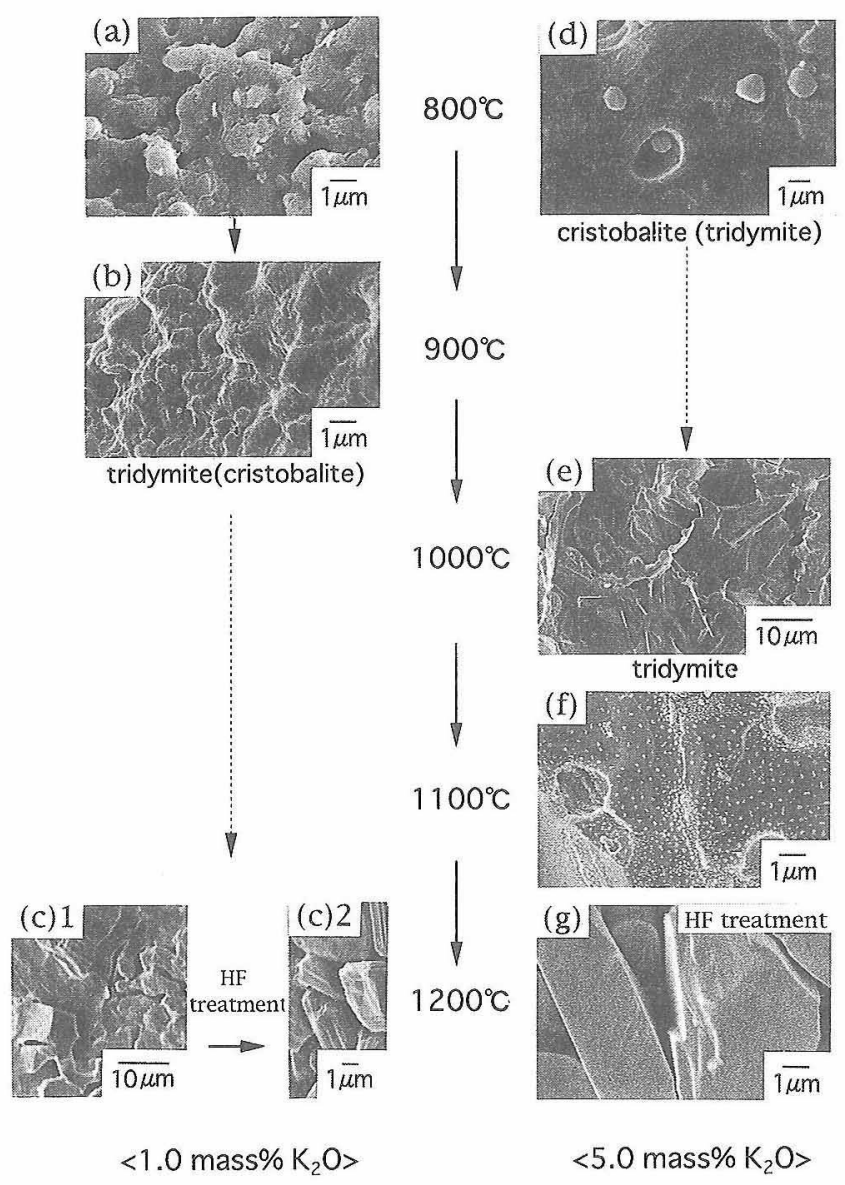

Fig. 8. SEM photographs of sintered spherical silica with $\mathrm{K}_{2} \mathrm{O}$ addition.

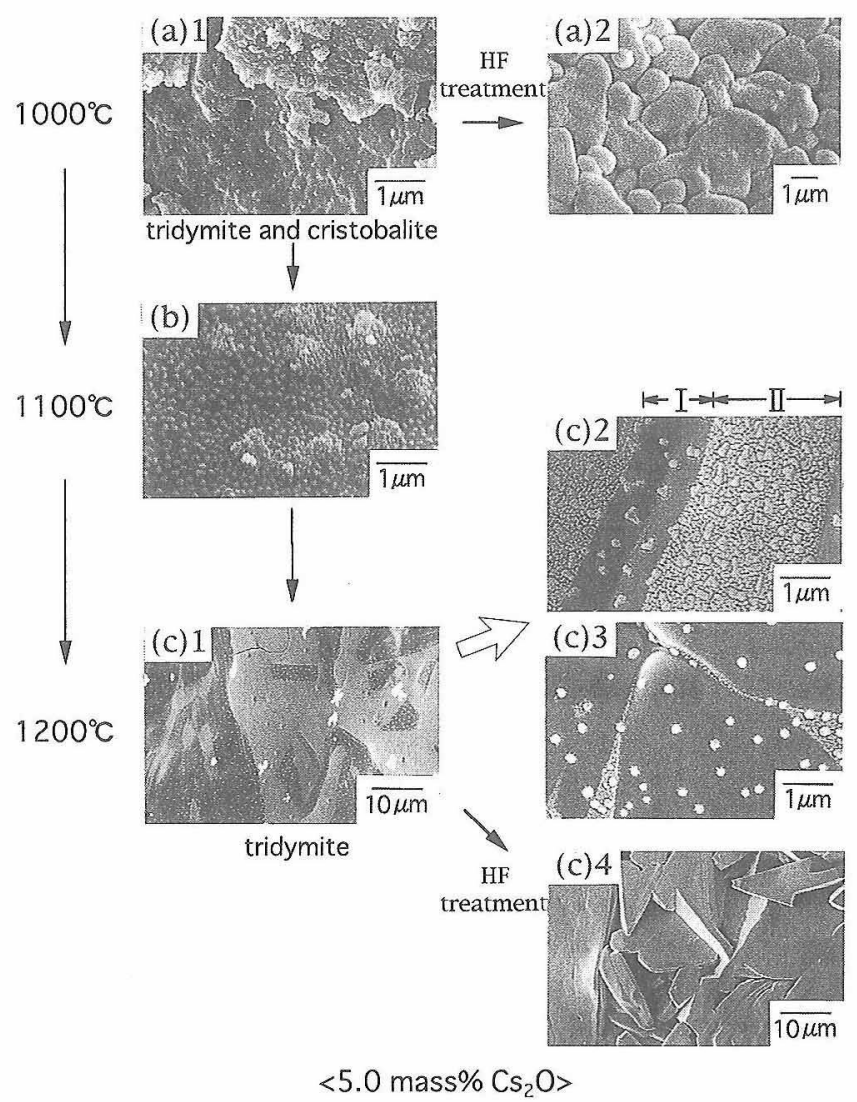

Fig. 9. SEM photographs of sintered spherical silica with 5.0 mass $\% \mathrm{Cs}_{2} \mathrm{O}$ addition.
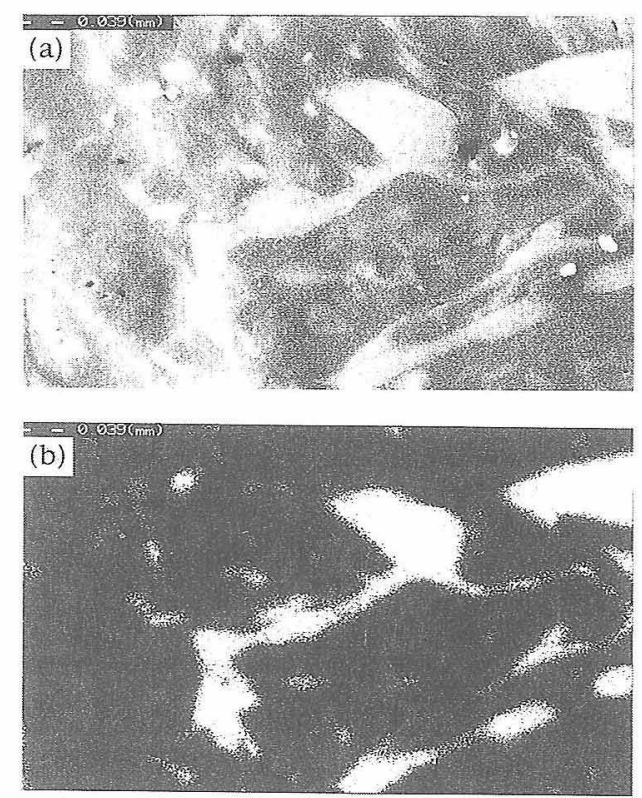

Fig. 10. EPMA images of sintered spherical silica with 5.0 mass \% $\mathrm{Cs}_{2} \mathrm{O}$ addition. (a) back scattered electron image, (b) $\mathrm{Cs}$ $\mathrm{K} \alpha \mathrm{X}$-ray image.

微粒子は $\mathrm{K}_{2} \mathrm{O}$ の場合(図 8 (f))でも見られ，1200 ${ }^{\circ} \mathrm{Ckなると，}$ シリカ鈤成体は図 9 (c) 4 に示すシリ力結晶相 I（トリディマ イト）と微粒子の集合相吕とに分相した（図 $9(\mathrm{c}) 2,3)$ ，この 面についてEPMA で組成分析を行った結果，図10に示すよう にCSイオンが集合相エのみに存在していることが確認され た.

以上の結果から，シリ力焼成体は加えられたアルカリ金属酸 化物の種類と添加量及び狫成条件により，シリ力融合体を形成 し石英やキ一タイトの結晶を形成する。㘯るいは，溶融層を形 成し, クリストバライトとトリディマイトの結晶相を生じる.

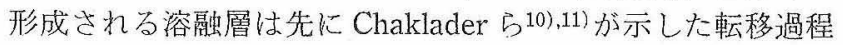
で生成する非晶質相と同様なものと考えられる。溶融層はアル 力リ金属酸化物の種類と添加量により形成状態が異なり，イオ ソ半径が大きく添加量の多いほぼ溶融度が高い，成長したクリ ストバライト及びトリディマイトの結晶中にはアルカリ金属が ほとんど含まれず，アルカリ金属イオンはケイ酸塩を生成して 集合相を形成し，分相した形で存在すると思われる。

3.6 アルカリ金属酸化物を添加したシリカの結晶化と相転 移に対する考察

以上，得られた結果を踏まえて，シリカの結晶化と相転移に 及ぼすアルカリ金属酸化物の影響について考察する。球状シ リ力の昇温焼成による組織の变化は, 球状シリ力の焼結機 構 25,26$)$ 及び DTA 曲線, 収縮率測定などから考察でさる。 DTA 曲線に抢いて $300 \sim 500^{\circ} \mathrm{C}$ 付近に幅広く見られる発熱ピー クと $400^{\circ} \mathrm{C}$ 加ら生じている成形体の収縮率の変化から, 球状シ リ力粒子内では温度上昇に伴い，ランダムに存在したシリカの 基本四面体構造であるケイ酸イオン $\left(\mathrm{SiO}_{4}{ }^{4-}\right)$ が縮合し再配列 が始をる. 同時に桲成処理により球状シリ力粒子同士の焼結が 進行し，ガラスに類似した相が形成されると推察される.

この過程に抢いてアルカリ金属酸化物が存在すると, 球状シ リカ粒子は非常に乱れた状態をとっているため, 添加したアル カリ金属イオンは容易に拡散しケイ酸イオンと反応することが

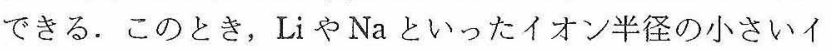
オンは, シリ力構造の間隙に存在し移動しやすい. なた, 添加 
量の少ない場合は，ケイ酸イオンの縮合反応を阻害せず,むし ろケイ酸イオンの再配列を促進する効果を示し結晶化が始ま る. その結果, 非晶質よりキータイトや石英といった各温度で 安定な相を形成する。添加量の多い場合は，シリカの Si-O 結 合を多く切断するため結晶相の成長を阻害する働きが強くな る、そしてシリカの一部に溶融層を形成することになり，この 溶融層を通してクリストバライトやトリディマイトが形成され るものと推察される.

一方, $\mathrm{K}, \mathrm{Rb}$ 及び Cs イオンの場合は，イオン半径が $\mathrm{Li}$ $\mathrm{Na}$ と比較して大きいために, シリカの $\mathrm{Si}-\mathrm{O}$ 結合を切断して 溶融層を形成する傾向がある，として，Naの添加量が多い場 合と同様にクリストバライトやトリディマイトが形成される. クリストバライトやトリディマイトの結晶構造の基本骨格は同 じであり，六角環の中心に大きな空所を有するが，キータイト や石英の結晶構造にはこのような空所が存在せず27), アル力 リ金属イオンを結晶内に取り込むことはほとんどない。した がって，溶融層から形成される結晶相はクリストバライト，卜 リディマイトを生じると推察できる.なお，いずれのアルカリ 金属酸化物も，添加量が少ないとクリストバライトを形成する 傾向を示し，添加量が多いとトリディマイトを形成する傾向上 なった。これは Flörke ${ }^{28)}$ が検討した結果と一致した。

今回得られた結果では, 従来, 高温安定相とされるクリス卜 バライトから低温安定相とされるトリディマイトへの転移が認 められた。 過去にもこのような転移挙動が報告されている12). 熱力学的には, 結晶構造の面からもクリストバライトの方がト リディマイトより安定であると言われているが, 乱れた構造を もつシリカでは Si-O 結合の切断の数まで考慮すると, 必ずし もクリストバライトが安定とは限らないとの指摘がある27)。

したがって, 構造が乱れた状態にある球状シリ力では, ある温 度範囲に打いてトリディマイトの方が安定という可能性があ る.よってオストワルドの階段通則に従うと, まず不安定な相 からクリストバライトが結晶化し，つぎに安定なトリディマイ トに変化するものと考えられる。

\section{4. 結 論}

ゾル-ゲル法で調製した非晶質の単分散球状シリカ粒子をシ リカ原料として用いた。この球状シリカの焼結に伴う結晶化と 相転移におけるアルカリ金属酸化物の影響を検討した。その結 果, 各種のアルカリ金属酸化物を添加した球状シリカは, 焼成 温度によって，それぞれ異なる結晶相を形成した。アルカリ金 属酸化物を添加したシリカの結晶化と相転移挙動は, 次にま之 められる。

$$
\begin{aligned}
\text { 非晶質 } & \text { キータイトー石英 } \\
& \rightarrow \text { }
\end{aligned}
$$

キータイト及び石英は $\mathrm{Li}_{2} \mathrm{O}$ や $\mathrm{Na}_{2} \mathrm{O}$ を添加した場合で結晶 化した。クリストバライトとトリディマイトの転移は添加され たアルカリ金属酸化物の濃度に依存すると考えられる。

アルカリ金属酸化物をシリカに添加した場合，アルカリ金属
イオンの拡散と形成する溶融層が結晶成長支配因子となり，シ リカの結晶化と相転移が起こると推察される．この溶融層はア ルカリ金属酸化物の添加量が多いほど形成されやすく, シリカ の結晶化と相転移に影響を与える。

(1995年 4 月，日本セラミックス協会年会にて一部発表）

謝 辞 本研究に打いて, X 線回折分析にご協力頂いた東海 大学工学部工業化学科・平方和則氏, 並びに EPMA による面組成 分析にご協力頂いた東海大学工学部金属材料工学科 ·宮本泰男氏 に深く感謝の意を表します

\section{文献}

1）貫井昭彦，セラミックス，20，266-73 (1985).

2) 貫井昭彦，耐火物，44, 479-83 (1992)。

3) W. D. Kingery, H. K. Bowen and D. R. Uhlmann, "Introduction to Ceramics," 2nd ed., Wiley-Interscience Publication (1976) pp. 85-88, pp. 269-318, pp. 505-07.

4）科学技術庁無機材質研究所研究報告書，第14号，5-19 (1977).

5）貫井昭彦，耐火物，44, 596-606 (1992).

6）貫井昭彦，ニューセラミックス，3，77-82 (1991).

7) 柳 奉奇, 坂村博康, 安井 至, J. Ceram. Soc. Japan, 101, 579-82 (1993).

8) G. Devand, C. Hayzelden, M. U. Azizand and D. Turnbull, J. Non-Cryst. Solids, 134, 129-32 (1991).

9) P. Bettermann and F. Liebau, Contrib. Mineral. Petrol., 53, 25-36 (1975)

10) A. C. D. Chaklader, J. Am. Ceram. Soc., 46, 66-71 (1963).

11) A. C. D. Chaklader and A. L. Roberts, J. Am. Ceram. Soc., 44, 35-41 (1961)

12) H. Schneider, O. W. Flörke and A. Majdic, Proc. Brit. Ceram. Soc., 28, 267-79 (1979).

13）鈴木隆夫，荒堀忠久，㶻協，89,637-42（1981）。

14） T. Arahori and T. Suzuki, J. Mater. Sci., 22, 2248-52 (1987).

15）加川博敏, 富田克利, 河野元治, 鹿児島大学理学部紀要（地 学·生物学), 24, 1-22 (1991).

16) G. I. Madden and L. H. Van Vlack, J. Am. Ceram. Soc., 50, 414-18 (1967).

17) W. Stöber, A. Fink and E. Bohn, J. Colloid Interface Sci., 26, 62-69 (1968)

18）下平高次郎，戸室 昇，粉体及び粉末冶金，23，137-42 (1976).

19）東 保男, 田島義巳, 大島信男, 末広建介, 窯協, 94, 55963 (1986).

20) A. Duran, C. Serna, V. Fornes and J. M. Fernandez Navarro, J. Non-Cryst. Solids, 82, 69-77 (1986).

21) F. Orgaz and H. Rawson, J. Non-Cryst. Solids, 82, 57-68 (1986).

22）浅賀喜与志，大門正機，石膏と石灰， 185, 43-47 (1983).

23）東 保男, 田島義巳, 大島信男, 末広建介, 寗協, 96, 13439 (1988).

24) E. R. Lippincott, A. V. Valkenburg, C. E. Weir and E. N. Bunting, J. Res. Natl. Bur. Stand., 61, 61-70 (1958).

25）鈴木 宏, 高木茂之, 森光英樹, 平野俱一, J. Ceram. Soc。 Japan, 100, 272-75 (1992).

26）科学技術庁無機材質研究所研究報告書, 第14号, 49-58 (1977).

27）橋本謙一, 浜野健也, “セラミックスの基礎”, 共立出版 (1977) pp. 18-38.

28） O. W. Flörke, Naturwissenschaften, 43, 419-20 (1956). 